\title{
Seri Poster Iklan "Petits Gâteaux" (Analisa Relasi Antar Tanda: Metafora-Metonimi)
}

\author{
Wantoro, S.Ds \\ Jurusan Desain Komunikasi Visual, Universitas Komputer Indonesia
}

\begin{abstract}
Abstrak. Sebagai sebuah media, poster sering digunakan sebagai media informasi untuk menyampaikan pesan penggunanya.Petits Gâteaux merupakan salah satu brand yang menggunakan media poster dalam kegiatan iklannya. Bersama sebuah agensi iklan Pheromone dari Kanada, Petits Gâteaux merilis 3 seri poster dengan tema "Petits Gâteaux, Cupcake Boutique : Small Cakes. Big Occasions". Yang menarik, ketiga poster tersebut memiliki kesamaan gaya komunikasi visual dimana satu sama lain saling terhubung dan membangun sebuah kesepahaman mengenai sebuah pesan.Hal ini terlihat dari penggunaan tanda-tanda visual dan relasinya yang digunakan dalam setiap poster.Melalui penelitian singkat ini, penulis akan mencoba memaparkan 3 seri poster Petits Gâteauxdan membedah penggunaan dan relasi tanda yang ada Petits Gâteaux guna mengetahui makna yang terkandung di dalamnya.
\end{abstract}

Kata kunci: Poster, Iklan, Tanda, Petits Gâteaux

\section{PENDAHULUAN}

Poster adalah salah satu media informasi dan persuasi yang banyak digunakan untuk menyampaikan pesan-pesan melalui bahasa visual dan tekstualnya. Dibandingkan media lain, poster sering dipilih untuk digunakan karena efektifitas dan efisiensinya.Salah satu penggunaan poster adalah dalam kegiatan iklan.

Petits Gâteaux merupakan salah satu (brand) kue/cake yang menggunakan media poster dalam mengiklankan produknya. Bersama agensi iklan Pheromone dari Kanada, pada bulan Mei 2012 ini Petits Gâteaux merilis 3 seri poster iklan dengan tema "Petits Gâteaux, Cupcake Boutique : Small Cakes. Big Occasions".Tiga seri poster iklan tersebut masing-masing diberi nama Cupcake Boutique Rose, Cupcake Boutique Ring \&Cupcake Boutique Champagne. 

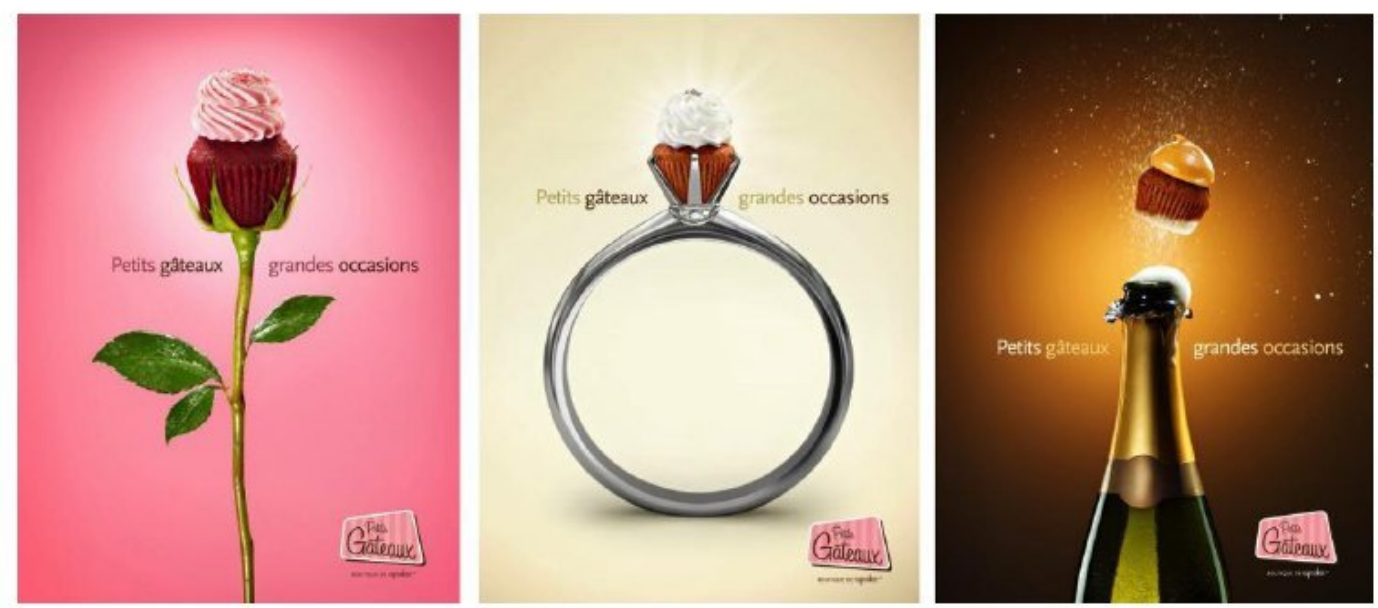

3 Poster Petits Gâteaux (kiri-kanan) : Rose, Ring \& Champagne

Sumber: adsoftheworld.com (19 Mei 2012).

Yang menarik, ketiga poster iklan tersebut menggunakan pendekatan dan gayakomunikasi visual yang paralel dan seirama dimana cake(kue) sebagai produk dari Petits Gâteaux digunakan sebagai simbol penanda dari pesan.Cake dikombinasikan dengan beberapa image(rose/bunga mawar, ring/cincin dan champagne) dan sekaligus diperankan sebagai pengganti sebagian dari imageimage tersebut untuk menyampaikan pesan.

Seri poster iklan Petits Gâteaux ini menarik untuk dikaji guna mengungkappesan/makna yang terkandung di dalamnya.Pada kajian ini, penulis akan menggunakan metode analisis semiotika dengan merelasikan beberapa tanda-tanda didalamnya (metafora-metonimi) sebagai "alat bedah" nya.Metode ini dipilih karena memiliki kedekatan relasi dengan obyek.

\section{METODE \& PEMBAHASAN}

Semiotika merupakan bidang studi yang mempelajari makna atau arti dari suatu tanda atau lambang (Sobur, 2004:11). Dalam semiotika, tanda merupakan basis dari seluruh komunikasi dan ikonisitas merupakan salah satu gejala yang penting di dalam semiotika. Charles Sander Pierce mencirikan ikon sebagai "suatu tanda yang menggantikan(stands for) sesuatu semata-mata karena ia mirip 
dengannya", sebagai suatu tanda yang "mengambil bagian dalam karakterkarakter objek" atau sebagai suatu tanda yang "kualitasnya mencerminkan objeknya, membangkitkan sensasi-sensasi analog di dalam benak lantaran kemiripannya." (Budiman, 2005:62).Ikon tidak hanya berupa tanda-tanda yang terdapat di dalam komunikasi visual, melainkan juga dalam hampir semua bidang semiotis, termasuk di dalam bahasa (Budiman, 2005:62) dimana salah satunya berada pada metafora.

Metafora disebutkan oleh Pradopo (1994:66) merupakan bentuk perbandingan dua hal secara langsung, tetapi dalam bentuk yang singkat. Metafora tidak harus selalu berbentuk verbal namun dapat juga berbentuk sebagai visual. Metafora visual juga dapat melibatkan sebuah fungsi 'pemindahan' (transference), memindahkan kualitas-kualitas tertentu dari sebuah tanda ke yang lainnya.

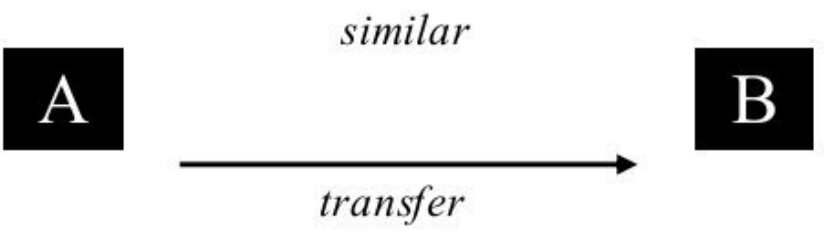

Selain metafora, ada pula yang disebut metonimi. Metonimi adalah suatu gaya bahasa yang mempergunakan sebuah kata untuk menyatakan suatu hal lain, karena mempunyai pertalian yang sangat dekat. Metonimi merupakan fungsi yang melibatkan penggunaan sebuah signified untuk menerangkan signified lainnya yang secara langsung berkaitan (directly related) atau diasosiasikan (closely associated) dengannya, dalam berbagai cara. Metonimi bukan kebalikan dari metafora, tapi dapatdikontraskan.

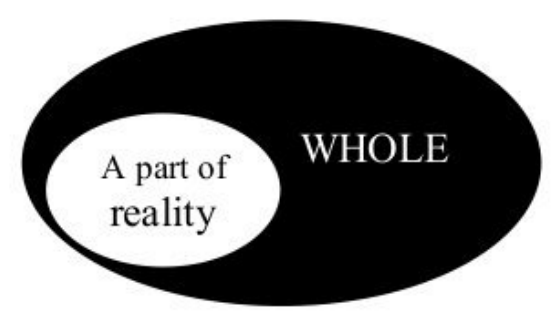


Dari paparan singkat di atas, maka untuk mengungkapkan makna dalam poster Petits Gâteaux, teks-teks sebagai tanda dalamposter tersebut harus diuraikan dan dianalisa terlebih dahulu utnuk kemudian direlasikan dan disimpulkan. Tanda dalam poster Petits Gâteaux terdiri dari beberapa elemen grafis seperti tipografi/teks dan fotografi/ilustrasi. Analisis terhadap tanda-tanda dalam poster tersebut dapat diuraikan sebagai berikut :

\section{A. Cupcake Boutique Rose}

Seri poster ini menggunakan latar belakang warna merah muda/pink, teks "Petits Gâteaux : Grandes Ocassion" dengan ilustrasi tangkai dan bunga mawar yang pada bagian bunganya diganti dengan cake yang merupakan produk dari Petits Gâteaux. Berikut analisa poster melalui relasi antar tanda (teori semiotika) dimana metafora dan metoni mi diungkapkan melalui pemecahan tanda.

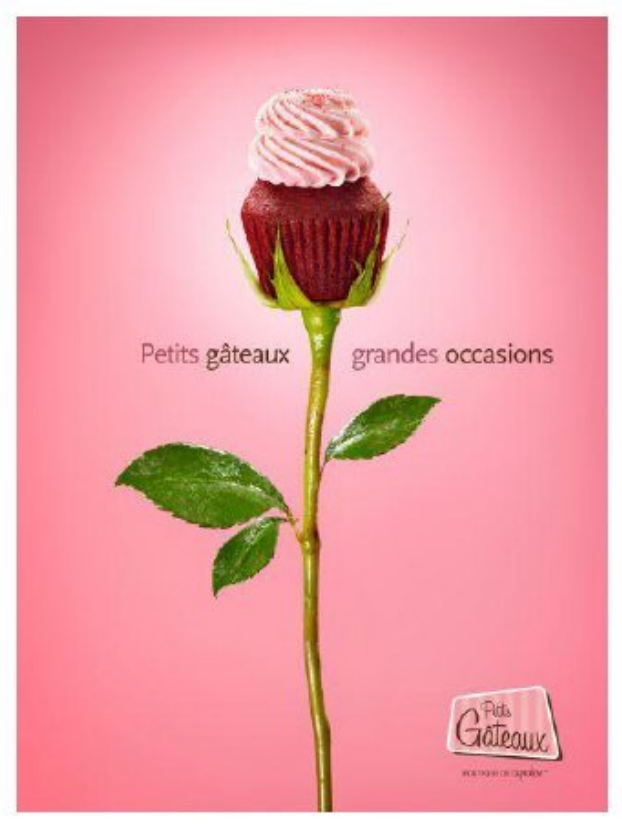

Seri Poster Cupcake Boutique Rose

\section{Metafora:}

Iconis $\rightarrow$ Cake - Rose (Bunga mawar) 
Ikonisasi dariobyek bunga mawar ke cakedimungkinkan karena adanya kesamaan/kemiripan (similarity) antara kedua obyek yaitu pada bentuk dan warna (merah) nya.

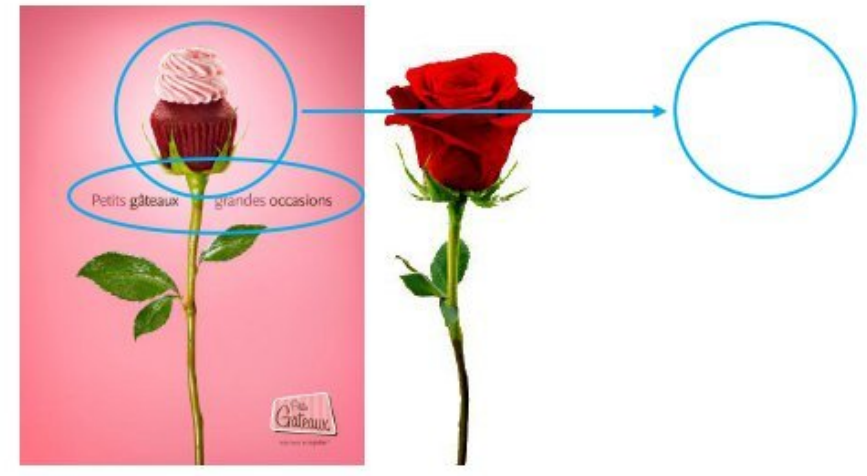

Rose/Bunga mawar yang dimetaforakan dalam cake Petits Gâteaux

\section{Fungsi Teks:}

Fungsi teks "Petits Gâteaux : Grandes Ocassion" pada iklan adalah untuk menjangkarkan makna.

\section{Metonimi:}

Gambar digunakan untuk menyampaikan konsep yang lebih besar: cinta, romantisme.Hal ini dikarenakan bunga mawar sering digunakan sebagai gift dalam hubungan percintaan untuk mengungkapkan rasa sayang/cinta.

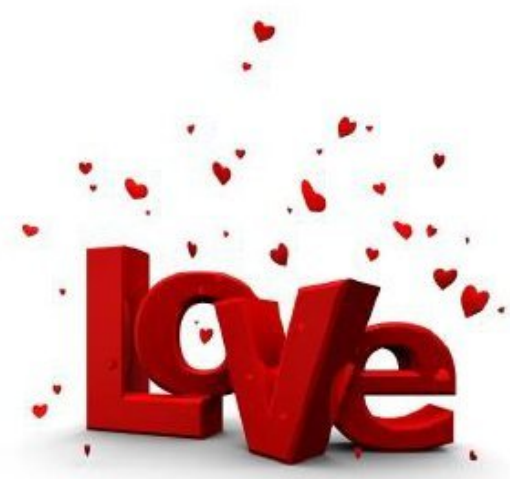




\section{Kesimpulan :}

Berdasarkan paparan atas relasi tanda pada seri poster iklan diatas, dapat disimpulkan bahwa cake Petits Gâteaux cocok digunakan untuk membangun romantisme dan kasih saying dalam hubungan percintaan dan berposisi setara dengan bunga mawar.

\section{B. Cupcake Boutique Ring}

Seri poster ini menggunakan ilustrasi utama berupa cincin yang pada bagian permata nya diganti dengan cake yang merupakan produk dari Petits Gâteaux dileng kapi teks "Petits Gâteaux : Grandes Ocassion" dengan latar belakang warna cream. Berikut analisa poster melalui relasi antar tanda (teori semiotika) dimana metafora dan metonimi diungkapkan melalui pemecahan tanda.

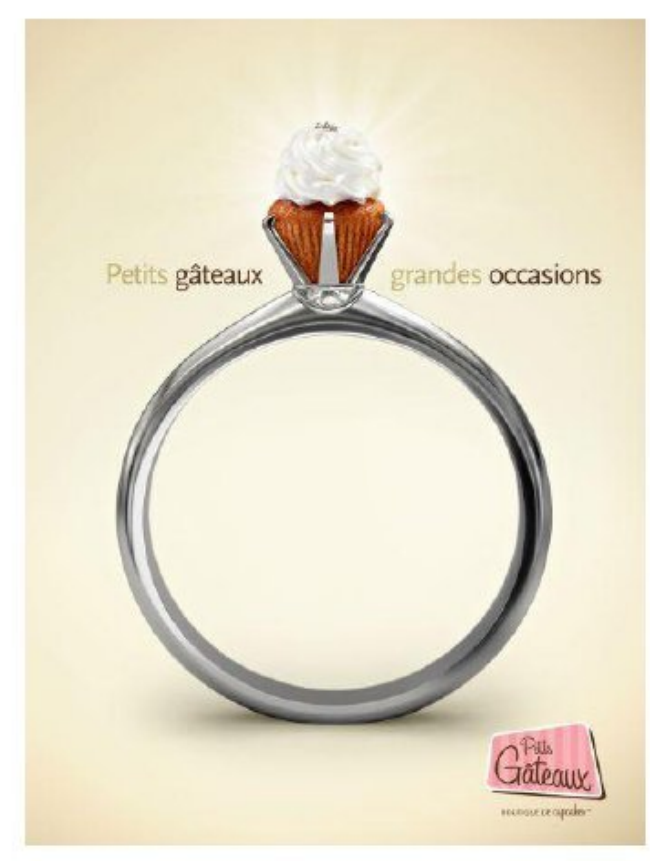

Seri Poster Cupcake Boutique Ring

\section{Metafora:}

Iconis $\rightarrow$ Cake - Mata Cincin 
"Penggantian" dilakukan perancang iklan karena adanya kesamaan/kemiripan (similarity) antara kedua obyek (permata pada cincin dengan cake) yaitu pada bentuk dan warnanya.

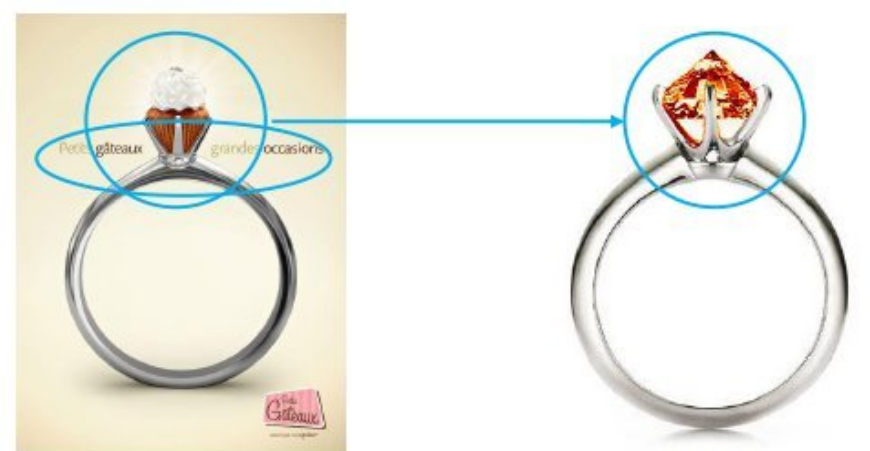

Permata pada ring/cincin yang dimetaforakan dalam cake Petits Gâteaux

\section{Fungsi Teks:}

Funsgi teks "Petits Gâteaux : Grandes Ocassion" pada iklan adalah untuk menjangkarkan makna.

\section{Metonimi:}

Gambar digunakan untuk menyampaikan konsep yang lebih besar: cinta, keterikatan, hubungan pertunangan/pernikahan. Perelasian antara ring/cincin dengan konteks dan konsep besar diatas dikarenakan cincin merupakan obyek yang selalu ada dalam prosesi penjalinan hubungan seperti pertunangan, pernikahan dan sebagainya.

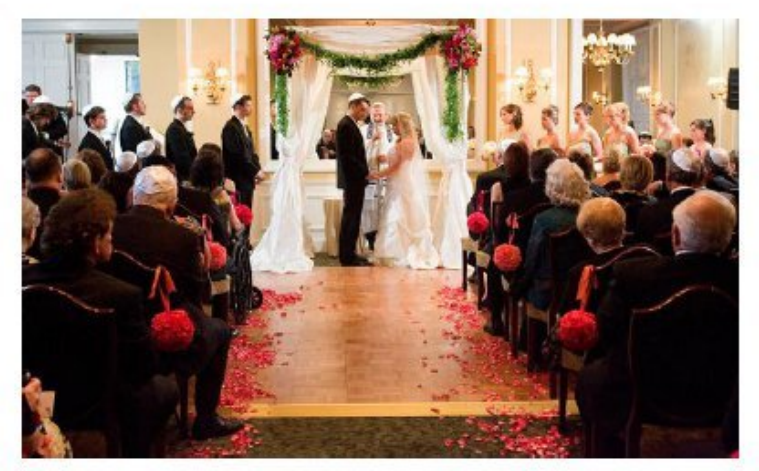

Pernikahan 


\section{Kesimpulan :}

Berdasarkan paparan atas relasi tanda (metafora-metonimi) pada seri poster iklan diatas, dapat disimpulkan bahwa cake Petits Gâteaux meski berukuran kecil namun sangat representatifuntuk digunakan sebagai simbol guna membangun dan merayakan hubungan percintaan (seperti pertunangan atau pernikahan) karena berposisi setara dengan cincin pernikahan.

\section{Cupcake Boutique Champagne}

Seri poster ketiga ini menggunakan teks tagline "Petits Gâteaux : Grandes Ocassion", ilustrasi berupa botol champagne yang pada bagian tutup botolnya diganti dengan cake yang merupakan produk dari Petits Gâteaux dengan latar belakang hitam emas. Berikut analisa poster melalui relasi antar tanda (teori semiotika) dimana metafora dan metonimi diungkapkan melalui pemecahan tanda.

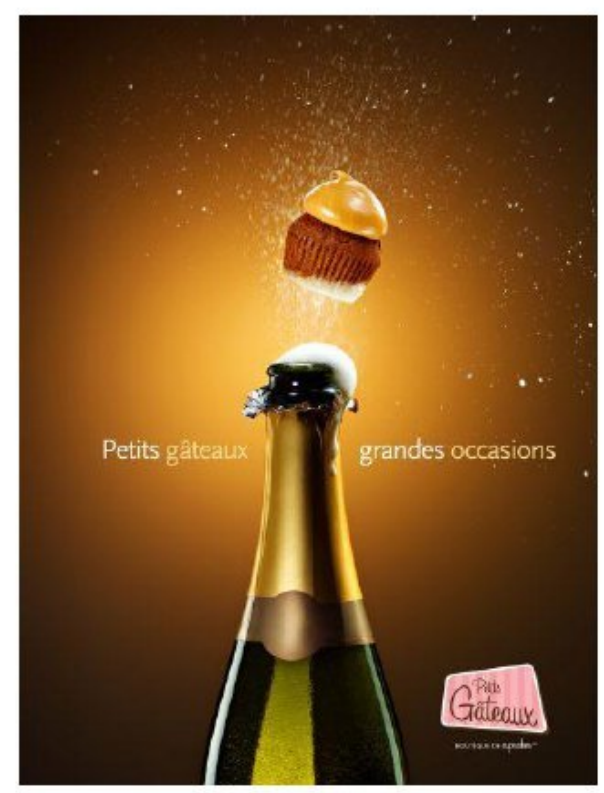

Seri Poster Cupcake Boutique Champagne

Sumber : adsoftheworld.com (19 Mei 2012).

\section{Metafora:}

Iconis $\rightarrow$ Cake - Tutup botol Champagne 
"Penggantian" karena adanya keserupaan (similarity) antara kedua obyek (tutup botol champagne dengan cake) yaitu pada bentuknya.

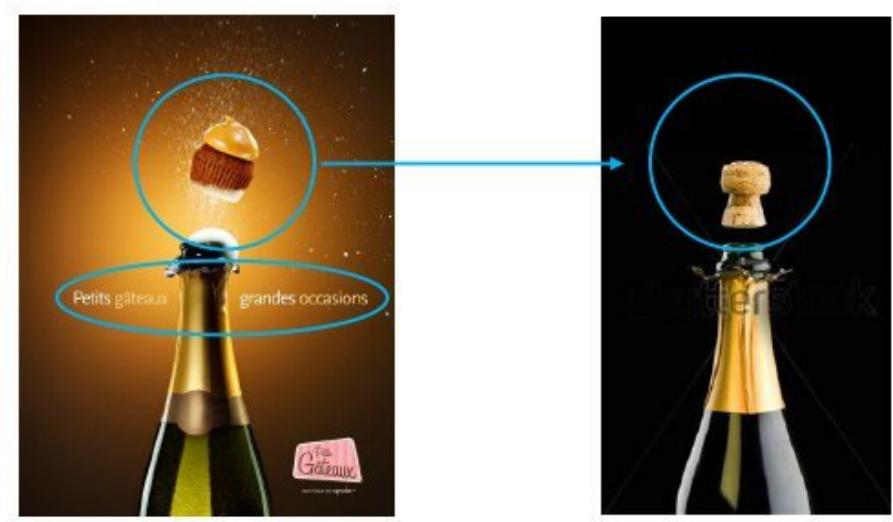

Tutup botol champagne yang dimetaforakan dalam cake Petits Gâteaux

\section{Fungsi Teks:}

Fungsi teks "Petits Gâteaux : Grandes Ocassion" pada iklan adalah untuk menjangkarkan makna yang terkandung di dalam iklan.

\section{Metonimi:}

Gambar digunakan untuk menyampaikan konsep yang lebih besar: pesta, selebrasi, perayaan, kemenangan.Perelasian ini dikarenakan karena champagne merupakan obyek khas yang selalu digunakan dalam perayaan-perayaan seperti perayaan juara di podium oleh pembalap yang meraih jua ra atau pada saat ulang tahun dan tahun baru.

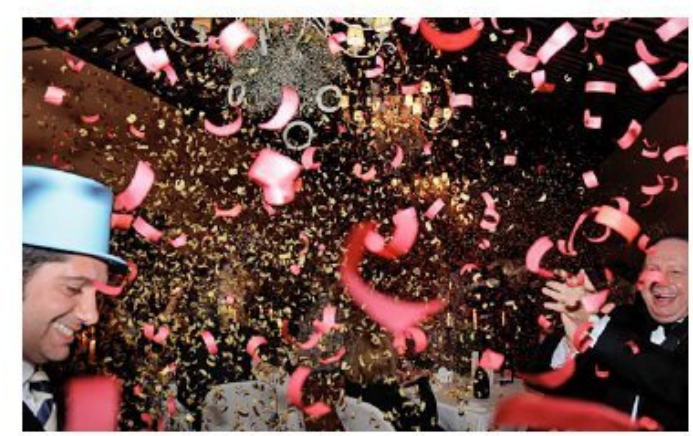

Selebrasi 


\section{Kesimpulan :}

Dari paparan atas relasi tanda (metafora-metonimi) pada seri poster iklan Cupcake Boutique Champagne diatas, dapat ditarik sebuah kesimpulan bahwa cake Petits Gâteaux meski berukuran kecil namun sangat representatif untuk digunakan sebagai hidangan/sajian pada saat perayaan, kesenangan seperti selebrasi kemenangan, ulang tahun, pesta dan sebagainya layaknya champagne.

\section{KESIMPULAN}

Dari uraian di atas dapat disimpulkan bahwamakna dalam seri posteriklanPetits Gâteauxdisampaikan menggunakan gaya metafora, dimana sang desainermenggunakanbeberapa elemen visual (rose/bunga mawar, ring/cincin dan botol champagne) yang pada bagiannya "digantikan" oleh visual cake dariPetits Gâteaux. "Penggantian" ini dimungkinkan karena selain adanya kemiripan visual (iconic) juga karena adanya asosiasi yang melekat pada brand/produk dengan konsep lain yang lebih luas (kemesraan, cinta, hubungan perniahan, perayaan). Pada akhirnya rangkaian tanda-tanda dalam poster ini melahirkan mitos baru mengenai Petits Gâteauxyaitu sebagai brand cake yang meskipun produknya berukuran kecil namun mampu dan cocok untuk dihadirkan dan dinikmati pada saat kejadian-kejadian penting dan besar di dalam hidup.

\section{DAFTAR PUSTAKA}

\section{- Buku}

Budiman, Kris. 2005. Ikonisitas: Semiotika Sastra Dan Seni Visual. Yogyakarta: Buku Baik.

Cobley, P. dan Litza Jansz.(2002). Mengenal Semiotika For Beginners. Terj. Ciptadi Sukono. Bandung: Mizan.

Nöth, W. (1995). Handbook of Semiotics.Bloomington: Indiana University Press.

Sobur, Alex. (2003). Semiotika Komunikasi. Bandung: Rosda. 


\section{- Handout Kuliah}

Piliang, Yasraf Amir. (2012). Handout Kuliah: Semiotika Desain. Bandung: Program Magister Desain ITB.

Piliang, Yasraf Amir \&Trisnawati, S. (2011). Handout Kuliah: Semiotika Desain. Bandung: Program Magister Desain ITB.

\section{- Internet}

http://adsoftheworld.com/media/print/petits_gateaux_cupcake_boutique_ro se(diakses pada 19 Mei2012)

http://adsoftheworld.com/media/print/petits_gateaux_cupcake_boutique_ri ng (diakses pada 19 Mei 2012) http://adsoftheworld.com/media/print/petits_gateaux_cupcake_boutique_ch ampagne (diakses pada 19 Mei 2012) 